Article Type: Research Paper

\title{
The Influence of Personality Factors on Entrepreneurial Intention
}

\author{
Isnanda Zainur Rohman ${ }^{1 *}$ and Miswanto ${ }^{1}$
}

\begin{abstract}
The aim of this paper is to examine the influence of personality factors (internal locus of control, need for achievement, and self-efficacy) on students' entrepreneurial intentions. The sample of this research was selected by using purposive sampling. The data were collected by survey using questionnaires. Respondents who filled the questionnaires were 200 university students, studying in Yogyakarta. The data were analyzed by using multiple regressions. The result showed that all of the personality factors in this study had positive effects on students' entrepreneurial intentions. In this study, it was found that the most significant variable to influence entrepreneurial intention was self-efficacy. The implication of this research is that if the number of entrepreneurs wants to be boosted, more attention must be paid to the personality factors of people

Keywords: Entrepreneurial Intention of Students; Personality Factors; Internal Locus of Control; Need for Achievement; Self-Efficacy.
\end{abstract}

THIS ARTICLE IS AVALILABLE IN:

http://journal.umy.ac.id/index.php/mb

DOI: $10.18196 / \mathrm{mb} .11293$

\section{CITATION:}

Rohman, I. Z., \& Miswanto. (2020) The Influence of Personality Factors on Entrepreneurial Intention. Jurnal Manajemen Bisnis, 11(2), 135-142.

\section{ARTICLE HISTORY \\ Received:}

04 December 2019

\section{Reviewed:}

31 December 2019

28 February 2020

Revised:

03 January 2020

03 March 2020

Accepted:

04 March 2020

\section{Introduction}

The number of employers is believed to affect the prosperity of a country (McClelland, 2013). Therefore, many things, which support the increasing number of employers, are essential. Entrepreneurial intention is a factor that is claimed to encourage the formation of employers (Sondari, 2014). Based on previous research, the entrepreneurial intention of students is closely linked to the possibility of becoming entrepreneurs. Countries could be prosperous when the number of people who become entrepreneurs is at least $2 \%$ of the total population. Therefore, it is crucial to improve the number of employers for a country's prosperity (Veleva \& Bodkin, 2018).

Entrepreneurs are people who can create new jobs for other people (Gartner \& Gartner, 2016). Those people are employed by entrepreneurs. It is said that becoming an entrepreneur is a good choice because it can provide employment. Entrepreneurs do not need to register themselves to work for other people. If a country has many entrepreneurs, the country will be wealthy. The other way around, if a country does not have many entrepreneurs, the country will be poor (Shehu \& Mahmood, 2014).

The role of entrepreneurs is pivotal in developed countries. It could be proven in the history of civilization and human progress. The contribution from entrepreneurs is great for economic development, and it happened in the western countries and Japan (Indarti, 2015). 
The self-employed workers are actively implementing changes to the environment, which can encourage a new economic society, resulting in additional revenue or increase productivity. It is recognized as the vital role of entrepreneurs in the development of developing countries, and it encourages all parties to foster entrepreneurial intention among the youth.

Some researchers have been focusing on entrepreneurial intention. Many studies have been conducted to assess the entrepreneurial intention and behavior of students. In their studies, the researchers raised the various factors affecting a people's intention to become entrepreneurs. In this study, the researcher focuses on entrepreneurial intention, which is influenced by personality factors.

\section{Literature Review and Hypotheses Development}

\section{Entrepreneurial Intention}

The word "entrepreneurship" comes from the French language (entreprende), meaning to undertake, to do, to run, and to try. Entrepreneurship is an entrepreneurial spirit that is built and aimed at bridging science and market capabilities. Entrepreneurship involves forming a new company. Entrepreneurs are people who move the economy's resources from low productivity to higher productivity levels. They produce more or become more productive people (Pogue, 2012). Entrepreneurial activities are also a managerial ability needed by an entrepreneur.

Many experts define entrepreneurship and self-employment. An entrepreneur is a person who has a creative and innovative effort at developing ideas and combining resources to find opportunities (McKenzie, Ugbah, \& Smothers, 2007). Entrepreneurs are people who reform or revolutionize production pattern by using the invention or newest technology to produce new commodities or produce old products in a new way (Beckman, Eisenhardt, Kotha, Meyer, \& Rajagopalan, 2012). Entrepreneurs are people who move the low-productivity economy's sources into sources of the high-productivity economy (Shaw, 2017).

The intention is feeling interested in an activity without anyone asking (Sheeran \& Webb, 2016). Furthermore, the intention of a person can be expressed through a statement and participation in an activity. The intention itself is a source of motivation to encourage someone to do what he wants.

Entrepreneurial intention is something inside the heart, feeling attractive to start running a business independently and to take risks (Obschonka, Silbereisen, \& SchmittRodermund, 2010). Several studies have mentioned that students' entrepreneurial intention is a source for a new generation of entrepreneurs. In this study, the entrepreneurial intention is defined as the intention of people to become entrepreneurs. 


\section{Internal Locus of Control}

Locus of control is a construct describing a perception of people's responsibility for everything, which happens in their life (Ajzen, 2002). Locus of control is a psychological construct that is used to identify a person's perception of affective self-control in terms of the external environment and the level of personal responsibility for the outcome (April, Dharani, \& Peters, 2012). Locus of control has two types. There is an internal locus of control and an external locus of control.

External locus of control is the extent to which a person expects and believes that the existing results are influenced by chance, luck, destiny, and other things that are uncertain and cannot be controlled. When a person is successful in his job, he will assume that it is because some things out of control, such as luck or other factors. Similarly, when he fails, he will assume that it is because of some things out of control.

Internal locus of control is the extent to which a person expects and believes that the results of his effort depend on his effort or personal characteristics. Someone who has an internal locus of control believes that he is responsible for the results. When he is successful in his job, he will assume that he has good abilities and has worked hard. Similarly, when he fails, he will assume that he does not do the best.

\section{Need for Achievement}

There are three kinds of theories of motivation needs. Those are the need for achievement, the need for affiliation, and the need for power. The need for achievement is a stable learning process, which will be obtained by struggling with satisfaction and meeting the highest level to be able to become experts in a specific subject (Schüler, Sheldon, \& Fröhlich, 2010).

The need for achievement is a learning pattern in which satisfaction will be obtained while working on a difficult task to achieve success (Sibin, Matthews, \& Dagher, 2007). The need for achievement is the desire to master the difficult challenges, compete with others, meet high standards, and have the desire to be proficient in a specific field (Winne \& Nesbit, 2010).

\section{Self-Efficacy}

Self-efficacy is a self-assessment of the ability to organize and carry out the actions necessary to achieve the specified performance. Efficacy itself provides the basis for human motivation, well-being, and personal achievement (Bandura, 2006). Self-efficacy is the confidence to know the ability to carry out a form of control over the benefits and events in the surrounding environment. Self-efficacy is a person's judgment about his ability to run a particular behavior or achieve specific goals (Shedler, 2010).

Self-efficacy can be a critical success and execution of work (Flammer, 2015). Selfefficacy also greatly affects the mindset, emotional reactions to making a decision. From 
some of these opinions, the researcher defines self-efficacy as the belief of in achieving specific goals.

\section{Hypotheses Development}

Entrepreneurs are people who have an internal locus of control (Luca, Cazan, \& Tomulescu, 2012). Someone who has an internal locus of control will see that the world is something that can be predicted, and individuals' behavior plays a role in it. The linkage between these two variables clearly shows that a person with an internal locus of control has higher entrepreneurial intentions.

$\mathbf{H}_{1}$ : Internal locus of control has a positive influence on entrepreneurial intention.

David McClelland developed research on people outside the campus who comprise various professions, including doctors, lawyers, bankers, teachers, employers, and others. The result is that employers have high scores of needs for achievement compared to other professions (McClelland, 2013). David McClelland also conducted research to determine the relationship between the economic development of a country and the need for achievement. The result was that the higher the scores of the need for achievement, the more country has entrepreneurs.

$\mathbf{H}_{2}$ : The need for achievement has a positive influence on entrepreneurial intention.

Many researchers believe that self-efficacy is related to career development. Selfefficacy will be a factor that describes a person's personal opinion related to career adjustment (Flammer, 2015; St-Jean \& Audet, 2012). Thus, a person's self-efficacy can be an essential factor in determining whether someone's entrepreneurial intention has been formed in the early stages of his career. Furthermore, the higher the level of selfefficacy on entrepreneurship in the early days of a person's career, the more powerful his entrepreneurial intention.

$\mathbf{H}_{3}$ : Self-efficacy has a positive influence on entrepreneurial intention.

\section{Research Method}

\section{The Source of Data and Sampling}

Primary data was used in this study. The samples of this research were the students of STIE YKPN Yogyakarta. The method of sampling used was purposive sampling. This method employed specific criteria. The criteria of respondents, who filled the questioners in this research, were students who were studying in Yogyakarta. 


\section{Analysis Methods}

A validity test was the first step of the analysis in the research. The validity test was done to demonstrate the ability of the questions in the questionnaire, whether it resulted in something that would be measured by the questionnaire. Testing the validity was carried out by using factor analysis in SPSS 26. Statement items in the questionnaire will be valid if it reaches a loading factor of more than 0.5 (Hair, Black, Babin, \& Anderson, 2010). The second test was the test of reliability. A reliability test was utilized to measure whether respondents answered consistently. If the respondents answered consistently, then the data would be reliable. The score of Cronbach's alpha used was higher than 0.6 (Hair et al., 2010). The higher the value of Cronbach's alpha, the better the reliability of research instruments. The third test was the classical assumption test. The classical assumption tests in this study were the normality test, multicollinearity test, and heteroscedasticity test. The fourth test was that the hypotheses test. A statistic tool utilized to test the hypotheses in this study was multiple regressions.

\section{Result and Discussion}

Based on the validity test results, all the item's loading factor scores were more than 0.5 . Thus, all the items on the statements of each variable were valid. In the reliability test, the score of Cronbach's alpha for each variable was more than 0.6. Based on this result, it can be concluded that all of the variables in this study were reliable. In the classical assumption, it is indicated that the data were normal, with no multicollinearity symptoms, and there was no heteroscedasticity. The last statistical test was multiple regressions. This test would answer whether the hypotheses were accepted or not. The table below shows the results of the three hypotheses.

Table 1 Hypotheses Results

\begin{tabular}{|c|c|c|c|}
\hline Hypotheses & $\beta$ & P-value & Conclusions \\
\hline $\begin{array}{l}\mathrm{H} 1 \text { : Internal locus of control has a positive influence } \\
\text { on the entrepreneurial intention }\end{array}$ & 0,104 & 0,036 & $\begin{array}{l}\text { hypothesis was } \\
\text { supported }\end{array}$ \\
\hline $\begin{array}{l}\mathrm{H} 2 \text { : Need for achievement has a positive influence on } \\
\text { entrepreneurial intention }\end{array}$ & 0,094 & 0,044 & $\begin{array}{l}\text { hypothesis was } \\
\text { supported }\end{array}$ \\
\hline $\begin{array}{l}\text { H3: Self-efficacy has a positive influence on } \\
\text { entrepreneurial intention }\end{array}$ & 0,774 & 0,001 & $\begin{array}{l}\text { hypothesis was } \\
\text { supported }\end{array}$ \\
\hline
\end{tabular}

\section{Discussion}

The Influence of Internal Locus of Control on Entrepreneurial Intention

It is claimed that an internal locus of control affects entrepreneurial intention. It is evidenced by recent studies, which found that the internal locus of control had a positive influence on entrepreneurial intention $(\beta=0.104 ; p<5 \%)$. This finding supports the previous research, which states that internal locus of control had a positive influence on entrepreneurial intention (Fong, Lam, \& Law, 2017; Karabulut, 2016; Luca et al., 
2012). Those who had an internal locus of control tended to work hard. They assumed that the result of the job was because of their hard work. It did not depend on luck.

The Influence of Need for Achievement on Entrepreneurial Intention

The need for achievement had a positive influence on entrepreneurial intention. It is proved in this study that the need for achievement had a positive influence on entrepreneurial intention $(\beta=0.094 ; p<5 \%)$. This finding supports the previous research, which concludes that the need for achievement positively affected entrepreneurial intention (Farouk, Ikram, \& Sami, 2014; Kolvereid \& Isaksen, 2012; Moneta, 2011). The higher level of need for achievement, the bigger the entrepreneurial intention. Those who had a high need for achievement tended to achieve something difficult. Related to the notion, being an entrepreneur is a challenging job, and being an entrepreneur is an achievement.

The Influence of Self-Efficacy on Entrepreneurial Intention

Self-Efficacy affected entrepreneurial intention. It is evidenced in this study that selfefficacy positively affected entrepreneurial intention $(\beta=0.774 ; p<5 \%)$. This finding supports the previous studies, which state that self-efficacy positively affected entrepreneurial intention (Mortan, Ripoll, Carvalho, \& Bernal, 2014; Pihie \& Bagheri, 2013; Tsai, Chang, \& Peng, 2016). People who had high self-efficacy tended to be more optimistic about becoming entrepreneurs. They were energetic to pursue themselves to be entrepreneurs. Self-efficacy was also the most influential variable in this study. Comparing the numbers of $\beta$ from all the dependent variables, the third variable had the biggest number of $\beta$. Therefore, self-efficacy had the biggest influence on creating an entrepreneurial intention.

\section{Conclusion}

This study contributes to the literature on the influence of personality on entrepreneurial intention. The result of the first regression analysis showed that the first hypothesis was proven to be supported in this study. Internal locus of control was proven to have a positive influence on entrepreneurial intention. People who believed that the things achieved were because of what they have done tended to have higher entrepreneurial intentions. Based on the result of the second regression analysis, hypothesis 2 was proven to be supported in this study. The need for achievement was proven to have a positive influence on entrepreneurial intention. Those who had a high need for achievement tended to have high entrepreneurial intentions. The third regression analysis finding was that the self-efficacy variable had a positive influence on entrepreneurial intention. Those who had a high level of confidence in the ability to be self-employed tended to have high levels of entrepreneurial intention. The last conclusion is about the most influential dependent variable. In this study, it was found that self-efficacy was the most influential dependent variable. The number of $\beta$ from the third variable was the highest, among others. 
This study has some limitations that may affect the results of the overall study. The sample of this research was university students. For the next research, it is much better if the researcher involves the other levels of education, such as junior high school, senior high school, and so on. This research only used three variables of personality factors. For the next research, it is better to add other personality variables, such as the big-five personality.

\section{References}

Ajzen, I. (2002). Perceived behavioral control, self-efficacy, locus of control, and the theory of planned behavior. Journal of Applied Social Psychology. 32(4), 665-683. https://doi.org/10.1111/j.1559-1816.2002.tb00236.x

April, K. A., Dharani, B., \& Peters, K. (2012). Impact of locus of control expectancy on level of well-being. Review of European Studies. 4(2). https://doi.org/10.5539/res.v4n2p124

Bandura, A. (2006). Guide for constructing self-efficacy scales. Self-Efficacy Beliefs of Adolescents. https://doi.org/10.1017/CBO9781107415324.004

Beckman, C. M., Eisenhardt, K., Kotha, S., Meyer, A., \& Rajagopalan, N. (2012). The Role of the Entrepreneur in Technology Entrepreneurship. Strategic Entrepreneurship Journal. 6, 203-206. https://doi.org/10.1002/sej.1136

Farouk, A., Ikram, A., \& Sami, B. (2014). The Influence of Individual Factors on the Entrepreneurial Intention. International Journal of Managing V alue and Supply Chains. 5(4), 47-57. https://doi.org/10.5121/ijmvsc.2014.5404

Flammer, A. (2015). Self-Efficacy. In International Encyclopedia of the Social \& Behavioral Sciences: Second Edition. 504-508. https://doi.org/10.1016/B978-0-08-0970868.25033-2

Fong, L. H. N., Lam, L. W., \& Law, R. (2017). How locus of control shapes intention to reuse mobile apps for making hotel reservations: Evidence from chinese consumers. Tourism Management. 61, 331- 342. https://doi.org/10.1016/j.tourman.2017.03.002

Gartner, W., \& Gartner, W. B. (2016). “Who is an Entrepreneur?” Is the Wrong Question. In Entrepreneurship as Organizing. https://doi.org/10.4337/9781783476947.00009

Hair, J. F., Black, W. C., Babin, B. J., \& Anderson, R. E. (2010). Multivariate Data Analysis. Vectors. https://doi.org/10.1016/i.ijpharm.2011.02.019

Indarti, N. (2015). Factors Affecting Entrepreneurial Intentions Among Indonesian Students. Journal of Indonesian Economy and Business. https://doi.org/10.22146/jieb.6585

Karabulut, A. T. (2016). Personality Traits on Entrepreneurial Intention. Procedia - Social and Behavioral Sciences. 229, 12-21. https://doi.org/10.1016/i.sbspro.2016.07.109

Kolvereid, L., \& Isaksen, E. J. (2012). The Psychology of the Entrepreneur. Perspectives in Entrepreneurship. 27-39. https://doi.org/10.1007/978-0-230-35809-6_3

Luca, M. R., Cazan, A. M., \& Tomulescu, D. (2012). To be or not to be an entrepreneur... Procedia - Social and Behavioral Sciences. 33, 173-177. https://doi.org/10.1016/j.sbspro.2012.01.106

McClelland, D. C. (2013). Entrepreneurial behavior. In The achieving society. 205-258. https://doi.org/10.1037/14359-006

McKenzie, B., Ugbah, S., \& Smothers, N. (2007). “Who Is an Entrepreneur?” Is It Still the Wrong Question? Academy of Entrepreneurship Journal. 
Moneta, G. B. (2011). Need for achievement, burnout, and intention to leave: Testing an occupational model in educational settings. Personality and Individual Differences. 50(2), 274-278. https://doi.org/10.1016/i.paid.2010.10.002

Mortan, R. A., Ripoll, P., Carvalho, C., \& Bernal, M. C. (2014). Effects of emotional intelligence on entrepreneurial intention and self-efficacy. Revista de Psicologia Del Trabajo y de Las Organizaciones. 30(3), 97-104. https://doi.org/10.1016/j.rpto.2014.11.004

Obschonka, M., Silbereisen, R. K., \& Schmitt-Rodermund, E. (2010). Entrepreneurial intention as developmental outcome. Journal of Vocational Behavior. 77(1), 63-72. https://doi.org/10.1016/j.jvb.2010.02.008

Pihie, Z. A. L., \& Bagheri, A. (2013). Self-Efficacy and Entrepreneurial Intention: The Mediation Effect of Self-Regulation. Vocations and Learning. 6, 385-401. https://doi.org/10.1007/s12186-013-9101-9

Pogue, D. J. (2012). Entrepreneur. In A Companion to George Washington. 70-85. https://doi.org/10.1002/9781118219935.ch5

Schüler, J., Sheldon, K. M., \& Fröhlich, S. M. (2010). Implicit need for achievement moderates the relationship between competence need satisfaction and subsequent motivation. Journal of Research in Personality. 44(1), 1-12. https://doi.org/10.1016/j.jpr.2009.09.002

Shaw, H. L. (2017). The Global Entrepreneur. https://doi.org/10.4324/9780203728802

Shedler, J. (2010). The Efficacy of Psychodynamic Psychotherapy. American Psychologist. 65(2), 98-109. https://doi.org/10.1037/a0018378

Sheeran, P., \& Webb, T. L. (2016). The Intention-Behavior Gap. Social and Personality Psychology Compass. 10(9), 503-518. https://doi.org/10.1111/spc3.12265

Shehu, A. M., \& Mahmood, R. (2014). The Impact of Business Environment on Entrepreneurship Performance in Nigeria. International Journal of Management Sciences.

Sibin, S., Matthews, S., \& Dagher, G. K. (2007). Need for achievement, business goals, and entrepreneurial persistence. Management Research News. 30(12), 928-941. https://doi.org/10.1108/01409170710833358

Sondari, M. C. (2014). Is Entrepreneurship Education Really Needed?: Examining the Antecedent of Entrepreneurial Career Intention. Procedia - Social and Behavioral Sciences. 115, 44-53. https://doi.org/10.1016/j.sbspro.2014.02.414

St-Jean, E., \& Audet, J. (2012). The role of mentoring in the learning development of the novice entrepreneur. International Entrepreneurship and Management Journal. 8(1), 119-140. https://doi.org/10.1007/s11365-009-0130-7

Tsai, K. H., Chang, H. C., \& Peng, C. Y. (2016). Extending the link between entrepreneurial self-efficacy and intention: a moderated mediation model. International Entrepreneurship and Management Journal. 12, 445-463. https://doi.org/10.1007/s11365-014-0351-2

Veleva, V., \& Bodkin, G. (2018). Corporate-entrepreneur collaborations to advance a circular economy. Journal of Cleaner Production. 20-37. https://doi.org/10.1016/j.jclepro.2018.03.196

Winne, P. H., \& Nesbit, J. C. (2010). The Psychology of Academic Achievement. Annual Review of Psychology. 61(1), 653-678. https://doi.org/10.1146/annurev.psych.093008.100348 